\title{
Induction of germination in Myxococcus xanthus fruiting body spores
}

\author{
Montserrat Elías and Francisco J. Murillo* \\ Departamento de Genética y Microbiología, Facultad de Biología, Universidad de Murcia, 30071 Murcia, Spain
}

(Received 9 May 1990; revised 3 October 1990; accepted 18 October 1990)

\begin{abstract}
Myxococcus xanthus, when starved on a solid surface, undergoes a multicellular cycle of development that consists of fruiting and sporulation. Myxospore germination has been followed in CTT, a complex medium composed mainly of peptides, by monitoring the sequential disappearance of some characteristic spore properties. Loss of heat resistance, shortly after incubation was initiated, was followed by loss of resistance to SDS and finally, refractility and ovoid shape. Germination of a population of myxospores did not occur synchronously. However, in the presence of calcium, germination was activated, being more rapid and synchronous. Other spore activation treatments tested did not have the same stimulatory effect. We searched for specific nutrients or chemicals capable of inducing germination. Amino acids, unlike other potential carbon and energy sources for $M$. xanthus, or several sugars tested, were most effective in triggering germination. Continuous incubation in CTT and Casamino acids germinant solutions was not required for induction and completion of germination of a large proportion of spores in a population.
\end{abstract}

\section{Introduction}

Cellular differentiation to resistant forms known as spores is a mechanism commonly exploited in nature, both by prokaryotic and by some simple eukaryotic organisms, to defend against adverse environmental conditions. The fruiting myxobacteria, however, are the only prokaryotes that exhibit a social behaviour associated with this cellular differentiation.

Myxococcus xanthus can grow vegetatively like other bacteria but, when nutrients become limiting, undergoes a primitive cycle of development. Thousands of cells move by gliding towards centres of aggregation to form fruiting bodies, where the long vegetative rods change to spherical optically refractile cells with resistance properties (Reichenbach, 1986). Considerable attention has been devoted to the fruiting and sporulation processes since they offer a relatively simple system to investigate how gene expression is controlled throughout development (for a review see Dworkin \& Kaiser, 1985). The germination process of fruiting body spores, however, has remained largely unknown, though it also appears to be a suitable model system to study the regulation of gene expression associated with cellular differentiation. In the same way as development, germination must depend on some mechanism which senses environmental conditions and processes possible chemical signals indicating that such conditions are no longer adverse.

Dworkin \& Gibson (1964) described a method for inducing rapid and synchronous conversion of vegetative cells into myxospores, without the intervening formation of fruiting bodies, by incubation in liquid medium containing glycerol. Previous reports on the physiology and early molecular analysis of myxospore germination are mostly related to germination of these glycerolinduced spores (Ramsey \& Dworkin, 1968, 1970; Juengst $\&$ Dworkin, 1973). The sporelike cells that result from glycerol induction differ in several structural and physiological aspects from fruiting body spores (Bacon \& Eiserling, 1968; Bacon et al., 1975; Inouye et al., 1979). Differences between the two types of spores have also been shown genetically (see review by Kaiser et al., 1979). Nevertheless, glycerol-induced spores and fruiting body spores are similar in some respects, namely morphological changes during sporulation and germination (Dworkin \& Voelz, 1962; Ramsey \& Dworkin, 1968), resistance properties (Sudo \& Dworkin, 1969), and coat components (Kottel et al., 1975; Sutherland \& Mackenzie, 1977).

We report here the results of some physiological studies on germination of fruiting body spores of Myxococcus xanthus. Comparison is made with previous reports on germination of glycerol-prepared spores.

\section{Methods}

Bacterial strains. $M$. xanthus DK 1050, a stable yellow derivative of the wild-type strain FB (Ruiz-Vazquez \& Murillo, 1984), was used as the parental wild-type strain for preparation of myxospores. Other $\mathbf{M}$ xanthus strains are introduced in the text. 
Media, chemicals, and growth conditions. CTT broth, routinely used to grow cultures, was prepared as described by Hodgkin \& Kaiser (1977). The notation $1 / n$ CTT refers to media derived from CTT by lowering the concentration of Bacto-Casitone by the factor $n$. To prevent variability due to calcium content, double-distilled water was used for all liquid media and chemical solutions prepared to assay germination. In all cases, the media were adjusted to $\mathrm{pH} 7.6$ and, where indicated, were supplemented with $\mathrm{CaCl}_{2}$.

L-Amino acids and D-sugars were purchased from Sigma.

Bacteria were grown at $33^{\circ} \mathrm{C}$ in $10 \mathrm{ml}$ of CTT broth in a $50 \mathrm{ml}$ Erlenmeyer flask and aerated by rotary motion at 250 r.p.m. Spores were developed on the CF fruiting agar (Hagen et al., 1978).

Preparation of myxospores. An exponentially growing culture was centrifuged at $3000 \mathrm{~g}$ for $10 \mathrm{~min}$ at $4^{\circ} \mathrm{C}$, the supernatant was decanted and the pellet resuspended in TPM buffer $(10 \mathrm{mM}-\mathrm{Tris} / \mathrm{HCl}, 8 \mathrm{mM}$ $\mathrm{MgSO}_{4}, 1 \mathrm{~mm}$-phosphate buffer, $\mathrm{pH}$ 7.6). After a second centrifugation, the pellet was resuspended in $1 / 4$ the original volume of fresh TPM buffer. Drops $(30 \mu l)$ of the concentrated cell suspension were micropipetted on to $\mathrm{CF}$ agar plates, allowed to dry at $33^{\circ} \mathrm{C}$, and incubated for $6 \mathrm{~d}$ at the same temperature.

Fruiting bodies were harvested by gently scraping the surface with an inoculating loop and were suspended in $5 \mathrm{ml} \mathrm{TPM}$ buffer. To disrupt the fruiting bodies and to kill the remaining vegetative cells, the samples on ice were sonicated in a sonic dismembrator (Dynatech, model 300 ) by three $30 \mathrm{~s}$ bursts, at a relative output of 0.7 . Spore suspension obtained after the sonication treatment was washed twice in TPM by centrifugation and stored at $4{ }^{\circ} \mathrm{C}$, at a cell density of $10^{8}$ spores $\mathrm{ml}^{-1}$, in TM buffer (10 mM-Tris/ $\left.\mathrm{HCl}, \mathrm{pH} 7.6,8 \mathrm{mM}^{-\mathrm{MgSO}_{4}}\right)$.

Germination assays. In all cases, myxospores were incubated at $33^{\circ} \mathrm{C}$, with continuous shaking, at a cell density of $10^{6}$ spores $\mathrm{ml}^{-1}$. Germination was followed by periodic examination using a phase contrast microscope. To monitor the loss of heat resistance, spore samples were treated at $50^{\circ} \mathrm{C}$ for $1 \mathrm{~h} 35 \mathrm{~min}$. When the fall in SDS resistance was used to follow germination, spores in TPM buffer were treated with $0.01 \%$ SDS for $25 \mathrm{~min}$. SDS was removed by centrifugation and resuspension in fresh TPM buffer. The number of initial and surviving spores after the corresponding treatment was determined by plating for single colonies on CTT agar.

To study the effect of pulse stimulation, spores were suspended in the solution to be tested, and samples taken at different times during incubation at $33^{\circ} \mathrm{C}$ were washed by centrifugation and then incubated at $33^{\circ} \mathrm{C}$ in TPM buffer.

\section{Results}

\section{Kinetics of germination}

During germination, fruiting body myxospores begin to lose their refractility and gradually elongate until a rod shape is assumed (Dworkin \& Voelz, 1962). Germination can therefore be monitored by microscopic observation of the morphological changes marking this process. Myxospores are more resistant to heat than the corresponding vegetative cells (Sudo \& Dworkin, 1969). Germination must therefore be accompanied by a lowering of heat resistance, and loss of this characteristic can also be used to monitor germination. Preliminary experiments carried out to establish the conditions appropriate for assaying germination by this criterion, indicated that spores still remained $100 \%$ viable after

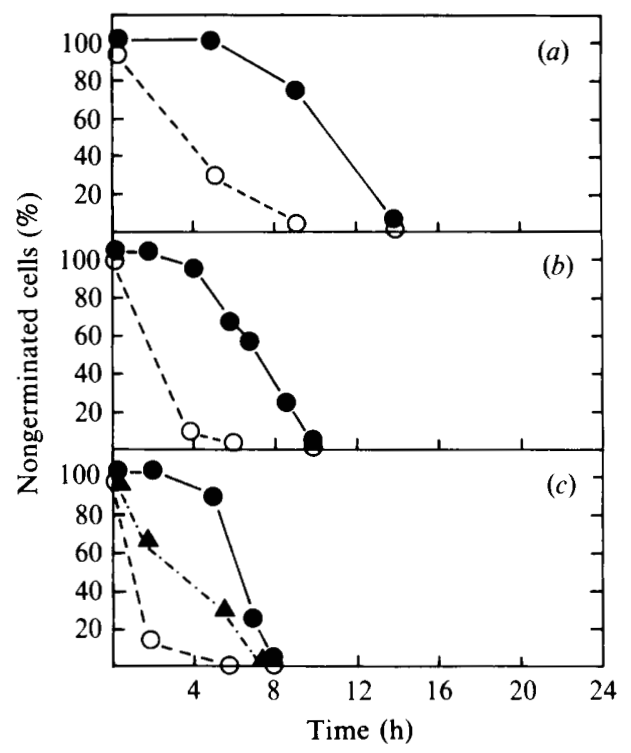

Fig. 1. Kinetics of germination of $M$. xanthus spores. The percentage of spores (still spherical and refractile) observed under the microscope (O) and the percentage of colony-forming units that were heat-resistant (O) were determined in (a) 1/30 CTT, (b) 1/10 CTT and (c) CTT. In (c), the percentages of colony forming units resistant to SDS treatment are also shown $(\boldsymbol{A})$.

$95 \mathrm{~min}$ at $50^{\circ} \mathrm{C}$, whereas vegetative cells were effectively killed after this time, the survival fraction being less than $10^{-5}$.

It has been reported previously that myxospores germinate readily when placed on solid CT medium, a rich growth medium containing a complex mixture of peptides (Dworkin \& Voelz, 1962). We studied the kinetics of germination in CTT broth, a very similar complex medium, and in its derivatives $1 / 10 \mathrm{CTT}$ and $1 / 30$ CTT. In each case, the loss of heat resistance occurred considerably faster than the loss of refractility observed under the microscope (Fig. 1). Germination occurred more rapidly as the concentration of Casitone was increased from $0.33 \mathrm{~g} \mathrm{l}^{-1}(1 / 30 \mathrm{CTT})$ to $10 \mathrm{~g} \mathrm{l}^{-1}$ (CTT).

Ramsey \& Dworkin (1968) reported that vegetative cells of $M$. xanthus were disrupted when treated with sodium dodecyl sulphate (SDS). On the other hand, fruiting body spores suspended in $0.1 \%$ SDS showed a normal appearance when examined with a phasecontrast microscope (Manoil \& Kaiser, 1980). In order to determine whether resistance to SDS could also be used to monitor germination, different concentrations and exposure times were tested. In all cases resistance to SDS was higher for myxospores than for vegetative cells (data not shown). From these results, treatment for $25 \mathrm{~min}$ in $0.01 \%$ SDS, which causes a loss of viability greater than $10^{5}$ for vegetative cells without affecting spore viability, was selected as the most appropriate condition for 
Table 1. Effect of calcium on germination induced by CTT and $10 \mathrm{mM}$-sodium acetate

Numbers are the percentage of germinated (nonrefractile, elongated) cells, observed under the microscope, after incubation for the indicated time in CTT (or $10 \mathrm{~mm}$-sodium acetate) alone, or CTT (or $10 \mathrm{~mm}$-sodium acetate) supplemented with $0.5 \mathrm{~mm}-, 1 \mathrm{mM}-, 2 \mathrm{mM}-$ or $5 \mathrm{mM}-\mathrm{CaCl}_{2}$. Numbers correspond to a single experiment, but similar results were obtained when the experiment was repeated.

\begin{tabular}{|c|c|c|c|c|}
\hline \multirow[b]{2}{*}{$\begin{array}{c}\text { Time } \\
\text { (h) }\end{array}$} & \multicolumn{4}{|c|}{ Germination in: } \\
\hline & $\begin{array}{l}\text { CTT } \\
\text { alone }\end{array}$ & $\begin{array}{c}\mathrm{CTT}+ \\
0.5 \mathrm{mM}-\mathrm{CaCl}_{2}\end{array}$ & $\begin{array}{c}\mathrm{CTT}+ \\
1 \mathrm{~mm}-\mathrm{CaCl}_{2}\end{array}$ & $\begin{array}{c}\mathrm{CTT}+ \\
2 \mathrm{mM}-\mathrm{CaCl}_{2}\end{array}$ \\
\hline 2 & 0 & 0 & 0 & 0 \\
\hline 5 & 27 & 53 & 63 & 92 \\
\hline $5 \cdot 5$ & 46 & 86 & 100 & 100 \\
\hline \multirow[t]{2}{*}{8} & 100 & 100 & 100 & 100 \\
\hline & $\begin{array}{c}10 \mathrm{~mm}- \\
\text { sodium acetate } \\
\text { alone }\end{array}$ & $\begin{array}{l}\text { Sodium acetate } \\
\quad 0.5 \mathrm{mM}-\mathrm{CaCl}_{2}\end{array}$ & $\begin{array}{l}\text { Sodium acetate } \\
\qquad \mathrm{mm}-\mathrm{CaCl}_{2}\end{array}$ & $\begin{array}{l}\text { Sodium acetate } \\
\qquad 5 \mathrm{mM}-\mathrm{CaCl}_{2}\end{array}$ \\
\hline 16 & 5 & 6 & 26 & 39 \\
\hline 22 & 25 & 29 & 36 & 44 \\
\hline
\end{tabular}

scoring germination. The fall in SDS resistance during germination in CTT occurred later than the loss of heat resistance but before the microscopical changes associated with germination were observed (Fig. 1c).

\section{Effect of calcium}

Stimulation by calcium of germination induced by other chemicals has been reported for many species of Bacillus and Clostridium (Russell, 1982; Douthit \& Preston, 1985). Addition of $\mathrm{CaCl}_{2}$ significantly improved the germination response of $M$. xanthus spores to CTT (Table 1). The effect was more evident as the concentration of $\mathrm{CaCl}_{2}$ was raised; whereas $8 \mathrm{~h}$ was required for germination to be complete in CTT alone, addition of $2 \mathrm{mM}-\mathrm{CaCl}_{2}$ shortened this period to $5 \mathrm{~h}$. Concentrations of $\mathrm{CaCl}_{2}$ higher than $5 \mathrm{mM}$ resulted in spore clumping without improving the stimulatory effect.

We have confirmed that the observed stimulation of germination by addition of $\mathrm{CaCl}_{2}$ is mediated by the calcium ions. The kinetics of germination remained the same in the presence of $\mathrm{MgCl}_{2}$ as in its absence, indicating that $\mathrm{Mg}^{2+}$ cannot substitute for $\mathrm{Ca}^{2+}$ (data not shown).

The effect of calcium alone was also studied. Ramsey $\&$ Dworkin (1968) reported that glycerol-induced spores were induced to germinate by $10 \mathrm{~mm}-\mathrm{Ca}^{2+}$. Unlike glycerol-induced spores, fruiting body spores suspended in $1-10 \mathrm{mM}^{-} \mathrm{CaCl}_{2}$ in TPM buffer or distilled water did not germinate, even after incubation for as long as $22 \mathrm{~h}$.
Protein S, an outer surface coat protein of $M$.xanthus spores, is assembled by a process that specifically requires $\mathrm{Ca}^{2+}$ (Inouye et al., 1979) and this protein shows several common features with eukaryotic calmodulin, another $\mathrm{Ca}^{2+}$-binding protein (Inouye et al., 1983). The possibility that the response of myxospores to $\mathrm{Ca}^{2+}$ was mediated by protein $\mathrm{S}$ was investigated. Strains DZ3359 and DZ3360 are mutants carrying a Tn5 insertion in the gene $(t p s)$, that encodes protein $\mathrm{S}$. Deletion mutants have also been constructed by removing the tps gene (D2), the extensively homologous ops gene (D1I) and both genes (D12) (Furuichi et al., 1985). All these mutants were as sensitive to calcium during germination as the parental wild-type strain DZF1. The extraction of protein S from the outer surface layer (Inouye et al., 1979) did not affect the response of spores to calcium (results not shown).

\section{Effect of acetate and pyruvate}

Acetate and pyruvate are potential energy sources for $M$. xanthus (Bretscher \& Kaiser, 1978) and are known to activate germination in some fungi (Brinckmann, 1960; Borchert, 1962: Delvaux, 1973). Acetate could act as a signal indicating appropriate nutritional conditions and activate germination of $M$. xanthus spores. However, while germination in CTT is complete after $8 \mathrm{~h}$ incubation, spores suspended in $10 \mathrm{~mm}$-acetate remained ungerminated within this period of incubation (Table 1). Only $25 \%$ germination was reached after $22 \mathrm{~h}$, indicating that acetate is much less effective than CTT in activating 


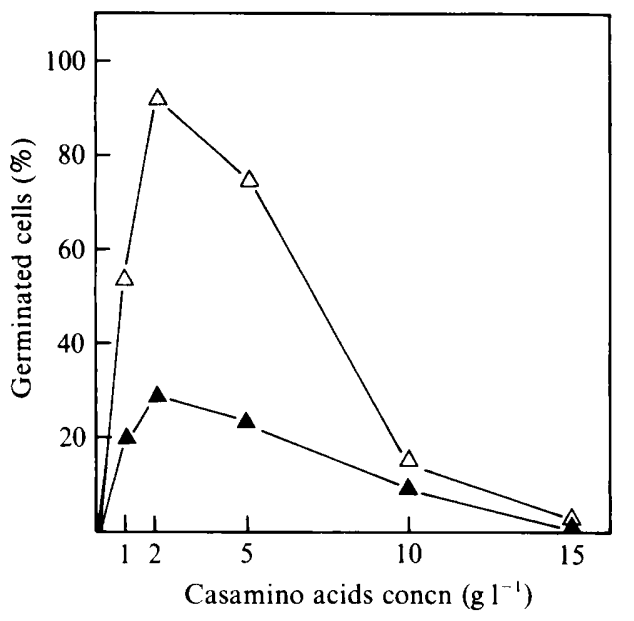

Fig. 2. Induction of germination by Casamino acids. The percentage of germinated cells, as observed under the microscope, after incubation for $10 \mathrm{~h}$ in Casamino acids at the indicated concentration was measured in the presence $(\triangle)$ or absence $(\Delta)$ of $1 \mathrm{mM}-\mathrm{CaCl}_{2}$.

germination. When $\mathrm{CaCl}_{2}$ was also present, myxospores showed an increased response to acetate. Myxospores incubated with pyruvate at the three concentrations tested $\left(1 \mathrm{mg} \mathrm{ml}^{-1}, 5 \mathrm{mg} \mathrm{ml}^{-1}\right.$ and $\left.10 \mathrm{mg} \mathrm{ml}^{-1}\right)$ failed to germinate.

\section{Effect of amino acids}

Germination of fruiting body spores at various concentrations of Casamino acids, an acid hydrolysate of casein which contains free amino acids among other nutrients, was studied (Fig. 2). Germination was maximal in $2 \mathrm{mg}$ Casamino acids $\mathrm{ml}^{-1}$ and was gradually inhibited as the concentration was increased. Casamino acids did not induce germination at concentrations above $10 \mathrm{mg} \mathrm{ml}^{-1}$. Addition of $1 \mathrm{~mm}-\mathrm{CaCl}_{2}$ favoured germination in Casamino acids below $5 \mathrm{mg} \mathrm{ml}^{-1}$ but for higher concentrations ( $10 \mathrm{mg} \mathrm{ml}^{-1}$ and $15 \mathrm{mg} \mathrm{ml}^{-1}$ ) no stimulatory effect was observed.

To search for more defined germination stimuli, the response to single amino acids or to combinations of these was studied. Eight out of fifteen amino acids tested induced germination to some extent when used individually at concentrations between $1 \mathrm{mg} \mathrm{ml}^{-1}$ and $10 \mathrm{mg}$ $\mathrm{ml}^{-1}$. The amino acids Lys, Phe, Pro and Arg were the most effective, inducing germination of about $20 \%$ of the spores, after incubation for $30 \mathrm{~h}$. Less effective were Ala, Ile, Leu, Ser, His, Thr, Tyr and Trp; Gly, Met and Val were completely ineffective at the concentrations used.

Induction of germination by three different mixtures (A, B, C) of amino acids was tested (Table 2). Mixture A, which contains three hydrophobic amino acids and has been used to induce germination in Dictyostelium
Table 2. Induction of germination by different mixtures of amino acids

Germination was observed under the microscope, after incubation for $20 \mathrm{~h}$ in the amino acid mixture alone, or in the mixture plus $1 \mathrm{mM}-\mathrm{CaCl}_{2}$. Numbers are the means of several experiments. Standard deviation never exceeded $10 \%$ of the mean.

\begin{tabular}{|c|c|c|}
\hline \multirow[b]{2}{*}{ Mixture* } & \multicolumn{2}{|c|}{ Germinated cells $(\%)$} \\
\hline & $\begin{array}{l}\text { Mixture } \\
\text { alone }\end{array}$ & $\stackrel{\text { Plus }}{1 \mathrm{mM}-\mathrm{CaCl}_{2}}$ \\
\hline A (Met, Phe, Trp) & 11 & ND \\
\hline $\begin{array}{l}\text { B (Pro, Tyr, Val, Ser, Thr) } \\
\text { B }_{1} \text { (-Pro) } \\
\text { B }_{2} \text { (-Tyr) } \\
\text { B }_{3} \text { (-Val) } \\
\text { B }_{4}(- \text { Ser }) \\
\text { B }_{5}(- \text { Thr })\end{array}$ & $\begin{array}{r}46 \\
4 \\
3 \\
14 \\
58 \\
60\end{array}$ & $\begin{array}{l}87 \\
20 \\
28 \\
50 \\
90 \\
81\end{array}$ \\
\hline $\begin{array}{l}\text { C (Lys, Ala, His, Ile, Leu) } \\
C_{1} \text { (-Lys) } \\
C_{2}(- \text { Ala }) \\
C_{3}(- \text { His }) \\
C_{4}(- \text { Ile }) \\
C_{5}(- \text { Leu }) \\
C_{6}(- \text { Ala, His, Ile, Leu })\end{array}$ & $\begin{array}{r}52 \\
4 \\
53 \\
42 \\
50 \\
44 \\
12\end{array}$ & $\begin{array}{l}85 \\
23 \\
79 \\
80 \\
87 \\
78 \\
31\end{array}$ \\
\hline
\end{tabular}

ND, Not determined.

* Each amino acid in mixture A, B or C (in parentheses) was present at a concentration of $1 \mathrm{mg} \mathrm{ml}^{-1}$. Mixtures $B_{1}-B_{5}$ and $C_{1}-C_{6}$ derive from mixtures $B$ and $C$, respectively, by omission of the amino acids indicated in parentheses.

discoideum (Cotter \& Raper, 1966), was the least active. Mixture B, consisting of Pro, Tyr, Val, Ser and Thr, and mixture C, composed of Lys, Ala, His, Ile and Leu, caused germination of a considerable percentage of spores, though the efficiency of induction was lower than that observed in CTT.

Mixtures B and C were studied more closely to determine if there were any conditions which could induce a more rapid or more complete germination response. Again, considerable improvement was achieved by addition of calcium, which resulted in a twofold increase in the percentage germination observed for the mixtures alone. Omission of Val, Pro and Tyr from mixture B significantly decreased germination, whereas omission of $\mathrm{Thr}$ and Ser showed a slight beneficial effect (Table 2). Thus, Val, ineffective when used singly and, to a greater extent, Pro and Tyr appear to be responsible for the stimulation observed with mixture B.

Omission of Lys from mixture $\mathrm{C}$ resulted in a marked decrease in germination (Table 2). However, the fact that when tested alone, Lys did not account for the percentage germination observed for the complete mixture led us to try some other combinations. Only if Lys was supplemented with His, but not with any other of the amino 
Table 3. Effect of heat shock on germination in CTT

Spore samples were incubated, for the time indicated, in TPM buffer, at $33^{\circ} \mathrm{C}(-)$ or $50^{\circ} \mathrm{C}(+)$, resuspended in CTT and incubated at $33^{\circ} \mathrm{C}$. Numbers are the percentages of germinated cells observed under the microscope.

\begin{tabular}{|c|c|c|c|c|c|c|c|c|}
\hline \multirow{3}{*}{$\begin{array}{l}\text { Incubation } \\
\text { time }(\mathrm{h})^{*}\end{array}$} & \multicolumn{8}{|c|}{ Germination after heat shock for (min): } \\
\hline & \multicolumn{2}{|c|}{5} & \multicolumn{2}{|c|}{15} & \multicolumn{2}{|c|}{30} & \multicolumn{2}{|c|}{60} \\
\hline & - & + & - & + & - & + & - & + \\
\hline 4 & 0 & 0 & 0 & 0 & 0 & 0 & 0 & 0 \\
\hline 5 & 20 & 15 & 10 & 0 & 0 & 0 & 0 & 0 \\
\hline 6 & 68 & 70 & 50 & 30 & 25 & 5 & 16 & 0 \\
\hline 7 & 87 & 86 & 86 & 82 & 66 & 21 & 48 & 5 \\
\hline 8 & 100 & 100 & 100 & 100 & 92 & 68 & 81 & 17 \\
\hline 9 & 100 & 100 & 100 & 100 & 100 & 84 & 90 & 50 \\
\hline
\end{tabular}

* Including the time that the spores were incubated in TPM buffer.

acids present in mixture $\mathrm{C}$, was the germination rate close to that obtained for the five amino acids together.

Other mixtures of amino acids tested did not stimulate germination as much as the most effective ones shown in Table 2. This was true even for mixtures of the most stimulatory amino acids, such as Pro, Tyr and Lys.

\section{Effect of sugars and heat treatments}

The sugars D-glucose, deoxy-D-glucose and D-glucosamine support appreciable germination of some bacterial spores (Hyatt \& Levinson, 1964). In M. xanthus, the mono- and disaccharides D-glucose, deoxy-D-glucose, Dglucosamine, D-maltose, D-arabinose, sucrose and lactose, at concentrations of $1 \mathrm{mg} \mathrm{m} l^{-1}$ and $10 \mathrm{mg} \mathrm{ml}^{-1}$, failed to trigger myxospore germination. Ramsey \& Dworkin (1968) also found that several sugars were ineffective in inducing germination of glycerol-prepared spores.

Finally, we tested heat shock, which is extensively used as an activation treatment in other sporulating organisms (Cotter \& Raper, 1966; Keynan \& Evenchik, 1969; Sussman, 1976). Spores in TPM buffer were shocked at different temperatures for various times and then incubated in CTT. Myxospores were killed when treated at $70^{\circ} \mathrm{C}$ for as little as five min (survival fraction less than $10^{-4}$ ) and no activation was found at $60^{\circ} \mathrm{C}$, which was also lethal when the shock lasted for more than 15 min (survival fraction less than $10^{-4}$ ). Although spores remained viable after $95 \mathrm{~min}$ at $50^{\circ} \mathrm{C}$ when plated for single colonies, microscopical observation showed that a treatment longer than $5 \mathrm{~min}$ at $50^{\circ} \mathrm{C}$ resulted in a delay in germination which was more pronounced as the duration of the shock was made longer (Table 3).
Working with glycerol-induced spores, Ramsey \& Dworkin (1968) also found that heating at $40{ }^{\circ} \mathrm{C}$ did not accelerate germination and that, if continued for more than $10 \mathrm{~min}$, it inhibited germination.

\section{Pulse stimulation}

The results presented so far were obtained by continuous incubation of spores in the germinant solution. However, one important question was whether complete germination required uninterrupted incubation in the germinant solution or whether contact with the germinant for a specific time would be enough to trigger germination. To clarify this point we carried out pulse stimulation experiments in CTT and Casamino acids.

When spores were pulse-stimulated in CTT (30$120 \mathrm{~min}$ ), germination was first observed under the microscope after incubation for $4 \mathrm{~h}$, increased gradually within the following $8 \mathrm{~h}$ and then levelled off. Incubation in CTT for $30 \mathrm{~min}, 60 \mathrm{~min}$ and $120 \mathrm{~min}$ was enough to stimulate germination up to $60 \%, 70 \%$ and $80 \%$, respectively, compared to $100 \%$ for continuous incubation (Fig. 3). Germination was also observed after pulsestimulation in Casamino acids $\left(2 \mathrm{mg} \mathrm{ml}^{-1}\right.$ for $30 \mathrm{~min}$ or $120 \mathrm{~min}$ ) although, as with CTT, pulse-stimulation was not as effective as continuous incubation in the same medium (Fig. 4). Note that induction by Casamino acids showed slower kinetics than induction by CTT and that germination did not level off until some time between 16 and $24 \mathrm{~h}$ incubation (Fig. 4).

In both media, as the duration of the pulse was increased the final percentage germination became higher. Exposure to the germinant solution for $2 \mathrm{~h}$, at which time no morphological changes were observed, 


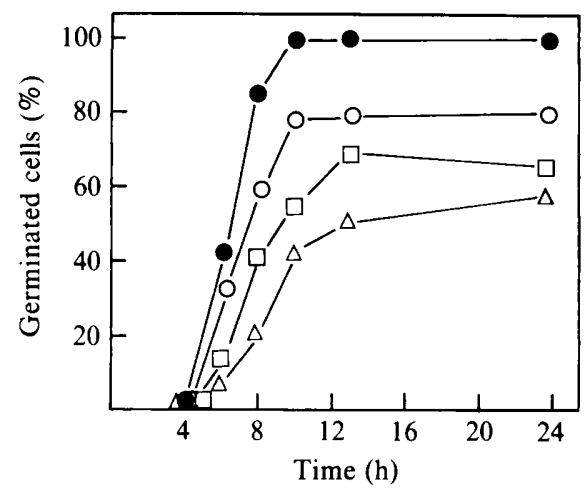

Fig. 3. Germination induced by pulse stimulation in CTT. Spores were incubated in CTT for $30 \mathrm{~min}(\triangle), 60 \mathrm{~min}(\square)$, or $120 \mathrm{~min}(O)$, then washed and resuspended in TPM buffer. Control spores (O) were incubated continuously in CTT. Germination was recorded by microscopic observation.

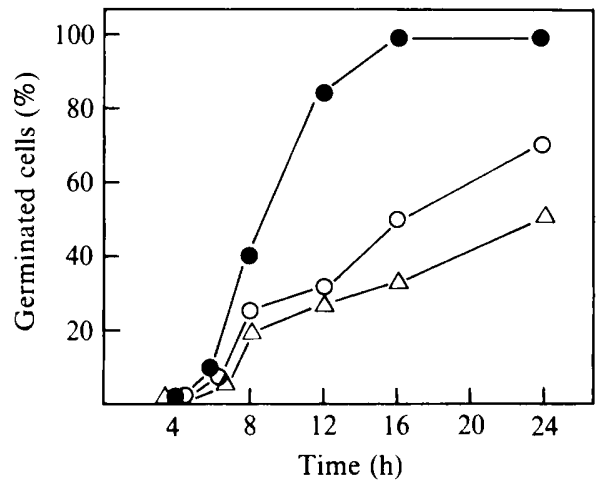

Fig. 4. Germination induced by pulse stimulation in Casamino acids. Spores were incubated for $30 \mathrm{~min}(\triangle)$ or $120 \mathrm{~min}(O)$ in $2 \mathrm{mg}$ Casamino acids $\mathrm{ml}^{-1}$, then washed and resuspended in TPM buffer. Control spores ( ) were incubated in Casamino acids continuously. Germination was recorded by microscopic observation.

was sufficient for a high percentage of spores to complete germination. Still longer incubation was needed for the majority of dormant spores to be activated, since continuous incubation results in $100 \%$ germination.

\section{Discussion}

The developmental cycle of Myxococcus xanthus is a good model system for the study of morphogenesis, cell differentiation and intercellular signalling. Considerable progress has been achieved in understanding how vegetative cells engage in fruiting body formation and sporulation (Kaiser et al., 1979; Dworkin, 1985). However, little work has focused on the events that take place during spore germination. Here, we present data concerning the loss of some characteristic properties of the spore during germination and the kind of nutritional signals that might induce this process in $M$. xanthus.

The initiation of germination leads to the sequential loss of the spore properties. Heat resistance is lost first, followed by resistance to SDS, and finally phase darkening and elongation occur. In Bacillus, loss of resistance to heat and to chemicals also precedes the first morphological changes (Levinson \& Hyatt, 1966). The curves presented in Fig. 1 reveal that in a population of germinating myxospores these events overlap to some extent, so that the process is not altogether synchronized. In particular, when the process is followed microscopically, germination does not occur simultaneously but is progressive after a lag phase during which there is no variation in the spore property being measured. Staggered germination is probably a consequence of differences in dormancy among the spores in a population and this may be advantageous in that it prevents germination of the whole population in response to a transient improvement in the nutritional conditions. The idea of variability amongst the population of myxospores is supported by the pulse experiments, in particular the data in Fig. 3.

Asynchrony is less remarkable when germination is estimated by the reduction in resistance to heat or SDS. In $M$. xanthus, the mechanism of heat resistance has not been elucidated. Studies with the bacterial endospore suggest that the basic mechanism concerns the water relations of the cell and, in particular, the maintenance of a low water content (Murrell \& Scott, 1966; Gerhardt \& Murrell, 1978; Warth, 1985). The refractile appearance of myxospores is indicative of partial dehydration and suggests that myxospores could be protected against heat through a similar mechanism. A change in spore permeability as an early event after induction of germination could result in a rapid intake of water and the subsequent loss of heat resistance. However, this explanation is not entirely satisfactory, as loss of refractility does not correlate with loss of heat resistance. Resistance to SDS is probably due to the thick coat surrounding the spore. During germination, this coat must be subject to degradation so as to facilitate release of the germinating cell and this would render the cell liable to attack by the detergent. In fact, electron micrographs of germinating myxospores reveals that elongation is preceded by the casting off of a sheath, which may be cell wall material (Dworkin \& Voelz, 1962).

Although changes in spore properties, particularly morphological changes, take a long time to manifest themselves, data from pulse stimulation experiments suggest that some spores are quick to sense and respond to variations in the environmental conditions (Figs 3 and 4). 
Spores of some organisms such as Dictyostelium discoideum and Phycomyces blakesleeanus are constitutively dormant and thus do not germinate unless an activation treatment is used (Sussman, 1976). After activation, these spores germinate rapidly and synchronously. With the exception of calcium, none of the treatments found to activate germination in other sporulating organisms served to increase the response of myxospores to germinants. Germination proceeded in the absence of added $\mathrm{CaCl}_{2}$, but in its presence the time required to observe the first morphological changes was reduced and the synchrony of the process increased (Table 1).

In Streptomyces it has been suggested that calsium ions activate germination by acting externally to the cytoplasmic membrane (Eaton \& Ensign, 1980). The molecular basis for activation by calcium in $M$. xanthus could also involve conformational changes of membrane proteins that might facilitate interactions between the germinants and their receptors. Our results show that protein S, an abundant spore surface coat protein with high calciumbinding affinity does not mediate the activation of germination produced by this metal ion.

Our search for nutritional signals capable of triggering germination has revealed that induction of germination in $M$. xanthus can be brought about almost exclusively by amino acids. This is consistent with the fact that all the organic nutritional requirements for vegetative growth of $M$. xanthus can be met by a mixture of amino acids (Dworkin, 1962). Starvation for amino acids has been reported to induce fruiting body formation and sporulation (Dworkin, 1963; Manoil \& Kaiser, 1980). However, spores are not induced to germinate by other potential carbon and energy sources for $M$. xanthus, with the exception of a minor effect of acetate. Several sugars tested were also ineffective. These observations indicate that amino acids not only play an important role during vegetative growth and fruiting, but also during germination.

Induction of germination is not restricted to a certain type of amino acid. Both polar and nonpolar amino acids are capable of initiating germination, either individually or as components of defined mixtures (Table 2). The amino acids Phe and Pro, which are among the most effective inducers of germination when tested alone, and the less active Tyr, Leu, Ile and Trp, have also been shown to be important for signal transmission early in fruiting body development (A. Kuspa, L. Plamann \& D. Kaiser, personal communication). The correlation is, however, not perfect; in particular Lys and Arg, which are good germinants, have low activity in signal transmission early in development.

Our results on the effect of amino acids on germination of fruiting-body spores do not quite correspond with a similar analysis carried out by Ramsey \& Dworkin (1968) on germination of glycerol-induced spores. At the concentration tested by those authors, glycerol spores were only induced to germinate by Gly, Ala, Val, Asp and Glu.

None of the individual amino acids or mixtures of those tested here induced germination with efficiency comparable to the complex media CTT and Casamino acids. This may be due to the presence in these complex media of traces of components other than amino acids. Alternatively, the germination apparatus might be designed to function preferentially in response to a complex mixture of amino acids or to short peptides.

We thank Maribel Carretero for technical assistance. We are grateful to David Zusman and Masayori Inouye for providing mutant strains. This work was supported by grant PB86-0416 from the Spanish Dirección General de Investigación Científica y Técnica.

\section{References}

BACON, K. \& EISERLING, F. A. (1968). A unique structure in microcysts of Myxococcus xanthus. Journal of Ultrastructural Research 21, 378382.

Bacon, K., Clutter, D., Kottel, R. H., Orlowski, M. \& White, D. (1975). Carbohydrate accumulation during myxospore formation in Myxococcus xanthus. Journal of Bacteriology 124, 1635-1636.

BorCHERT, R. (1962). Über die Azetat-Aktivierung der Sporangiosporen von Phycomyces blakesleeanus. Beiträge zur Biologie der Pflanzen 38, 31-61.

Bretscher, A. P. \& KaISER, D. (1978). Nutrition of Myxococcus xanthus, a fruiting myxobacterium. Journal of Bacteriology 133, 763768.

BrinckmanN, M. (1960). Über das die Keimung von Phycomyces Sporangiosporem fördernde Prinzip Leiss-sterilisierter GlucoseSubstrate. Archiv für Mikrobiologie 37, 161-187.

COTTER, D. A. \& RAPER, K. B. (1966). Spore germination in Dictyostelium discoideum. Proceedings of the National Academy of Sciences of the United States of America 56, 880-887.

Delvaux, E. (1973). Some aspects of germination induction in Phycomyces blakesleeanus by an ammonium-acetate pretreatment. Archiv für Mikrobiologie 88, 273-284.

Douthit, H. A. \& Preston, R. A. (1985) Activation of Bacillus cereus spores with calcium. In Fundamental and Applied Aspects of Bacterial Spores, pp. 297-307. Edited by G. J. Dring, D. J. Ellar \& G. W. Gould. London: Academic Press.

DworkIN, M. (1962). Nutritional requirements for vegetative growth of Myxococcus xanthus. Journal of Bacteriology 84, 250-257.

DWORKIN, M. (1963). Nutritional regulation of morphogenesis in Myxococcus xanthus. Journal of Bacteriology 86, 67-72.

DwORKIN, M. (1985). The myxobacteria. In Developmental Biology of the Bacteria, pp. 105-149. Edited by P. Elias \& G. Hubit. Menlo Park, Ca: Benjamin Cummings Publishing Co.

DWORKIN, M. \& Gibson, S. M. (1964). A system for studying microbial morphogenesis: rapid formation of microcysts in Myxococcus xanthus. Science 146, 243-244.

DWORKIN, M. \& KAISER, D. (1985). Cell interactions in myxobacterial growth and development. Science 230, 18-24.

DWORKIN, M. \& VOELz, H. (1962). The formation and germination of microcysts in Myxococcus xanthus. Journal of General Microbiology 28, 81-85.

EATON, D. \& ENSIGN, J. C. (1980). Streptomyces viridochromogenes spore germination initiated by calcium ions. Journal of Bacteriology 143, 377-382. 
Furuichi, T., Komano, T., Ino, M. \& Inouye, S. (1985). Functional complementation between the two homologous genes, ops and tps, during differentiation of Myxococcus xanthus. Molecular and General Genetics 199, 434-439.

GerhardT, P. \& MURRell, W. G. (1978). Basis and mechanism of spore resistance: a brief preview. In Spores VII, pp. 18-20. Edited by G. Chambliss \& J. C. Vary. Washington DC: American Society for Microbiology.

Hagen, D. C., Bretscher, A. P. \& Kaiser, D. (1978). Synergism between morphogenetic mutants of Myxococcus xanthus. Developmental Biology 64, 284-296.

HODGKIN, J. \& KAISER D. (1977). Cell-to-cell stimulation of movement in nonmotile mutants of Myxococcus. Proceedings of the National Academy of Sciences of the United States of America 74, 2938-2942.

HyATT, M. T. \& LeVINSON, H. S. (1964). Effect of sugars and other carbon compounds on germination and postgerminative development of Bacillus megaterium spores. Journal of Bacteriology 88, 14031415.

InOUYE, M., InOUYe, S. \& Zusman, D. R. (1979). Biosynthesis and selfassembly of protein S, a development-specific protein of Myxococcus xanthus. Proceedings of the National Academy of Sciences of the United States of America 76, 209-213.

Inouye, S., Franceschini, T. \& Inouye, M. (1983). Structural similarities between the development-specific protein $\mathrm{S}$ from a Gram-negative bacterium, Myxococcus xanthus, and calmodulin. Proceedings of the National Academy of Sciences of the United States of America 80, 6829-6833.

JuenGST, F. W. \& DWORKIN, M. (1973). Ribonucleic acid and protein synthesis during germination of Myxococcus xanthus myxospores. Journal of Bacteriology 113, 786-797.

KaISer, D., Manoll, C. \& Dworkin, M. (1979). Myxobacteria: cell interactions, genetics and development. Annual Review of Microbiology 33, 595-639.

Keynan, A. \& Evenchik, Z. (1969). Activation. In The Bacterial Spore, pp. 359-396. Edited by G. W. Gould \& A. Hurst. London: Academic Press

Kottel, R. H., Bacon, K. Clutter, D. \& White, D. (1975). Coats from Myxococcus xanthus: characterization and synthesis during myxospore differentiation. Journal of Bacteriology 124, 550-557.
Levinson, H. S. \& HyatT, M. T. (1966). Sequence of events during Bacillus megaterium spore germination. Journal of Bacteriology 91, $1811-1818$

Manoll, C. \& KaISER, D. (1980). Guanosine pentaphosphate and guanosine tetraphosphate accumulation and induction of $M$ yxococcus xanthus fruiting body development. Journal of Bacteriology 141, 305-315.

MurRell, W. G. \& ScoTt, W. J. (1966). The heat resistance of bacterial spores at various water activities. Journal of General Microbiology 43, 411-425.

RAMSEY, W. S. \& DWORKIN, M. (1968). Microcyst germination in Myxococcus xanthus. Journal of Bacteriology 95, 2249-2257.

RAMSEY, W. S. \& DWORKIN, M. (1970). Stable messenger ribonucleic acid and germination of Myxococcus xanthus microcysts. Journal of Bacteriology 101, 531-540.

REICHENBACH, H. (1986). The myxobacteria: common organisms with uncommon behaviour. Microbiological Sciences 3, 268-274.

Ruiz-Vázquez, R. \& MuRILlo, F. J. (1984). Abnorrnal motility and fruiting behavior of Myxococcus xanthus bacteriophage-resistant strains induced by a clear-plaque mutant of bacteriophage Mx8. Journal of Bacteriology 160, 818-821.

Russell, A. D. (1982). The bacterial spore. In The Destruction of Bacterial Spores, pp. 17-24. Edited by A. D. Russell. London: Academic Press.

SUDO, S. Z. \& DWORKIN, M. (1969). Resistance of vegetative cells and microcysts of Myxococcus xanthus. Journal of Bacteriology 98, 883887.

Sussman, A. S. (1976). Activators of fungal spore germination. In The Fungal Spore, pp. 101-139. Edited by D. J. Weber \& W. M. Hess. New York: John Wiley.

Sutherland, I. W. \& MaCKenZie, C. L. (1977). Glucan common to the microcyst walls of cyst-forming bacteria. Journal of Bacteriology 129, 599-605.

W ARTH, A. D. (1985). Mechanism of heat resistance. In Fundamental and Applied Aspects of Bacterial Spores, pp. 209-227. Edited by G. J. Dring, D. J. Ellar \& G. W. Gould. London: Academic Press 